\title{
Exendin 4 controls insulin production in rat islet beta cells predominantly by potentiation of glucose-stimulated proinsulin biosynthesis at the translational level
}

\author{
C. Alarcon • B. Wicksteed • C. J. Rhodes
}

Received: 21 April 2006/Accepted: 19 July 2006 / Published online: 20 October 2006

(C) Springer-Verlag 2006

\begin{abstract}
Aims/hypothesis Ideally, a therapeutic insulin secretagogue should coordinately increase insulin production and insulin secretion to maintain islet beta cell secretory capacity. We compared the incretin mimetic exendin 4 and the sulfonylurea glibenclamide (known as glyburide in the USA and Canada) for their effects in upholding a balance between (pro)insulin biosynthesis and insulin secretion in pancreatic islets.

Methods Isolated rat islets were incubated for 1 or $16 \mathrm{~h}$ over a range of glucose concentrations $(2.8-16.7 \mathrm{mmol} / \mathrm{l})$ with or without exendin $4(10 \mathrm{nmol} / \mathrm{l})$ or glibenclamide $(1 \mu \mathrm{mol} / \mathrm{l})$. Islets were then analysed for preproinsulin mRNA expression by RNase protection and quantitative real-time RT-PCR assays. Proinsulin biosynthesis was analysed by metabolic pulse-radiolabelling, immunoprecipitation and PAGE. Insulin secretion and insulin content were analysed by radioimmunoassay.

Results Neither exendin 4 nor glibenclamide affected islet preproinsulin mRNA expression. However, exendin 4 significantly increased glucose-induced proinsulin biosynthesis at the translational level within $1 \mathrm{~h}$, in marked contrast to glibenclamide, which inhibited proinsulin biosynthesis, especially at basal and intermediate glucose concentrations. Exendin 4 potentiated insulin secretion in a glucose-dependent manner, whereas glibenclamide stimulated insulin secretion independently of glucose. Exendin 4 better maintained rat islet insulin content compared with
\end{abstract}

C. Alarcon · B. Wicksteed · C. J. Rhodes $(\bowtie)$

Diabetes Center, Department of Medicine, Endocrine Division,

University of Chicago,

5841 S. Maryland Ave., MC 1027, Room N138,

Chicago, IL 60637, USA

e-mail: crhodes@medicine.bsd.uchicago.edu glibenclamide, which depleted intracellular stores of insulin in islet beta cells by $40 \%$ within $16 \mathrm{~h}$.

Conclusions/interpretation Exendin 4 maintains insulin stores and beta cell secretory capacity primarily by translational control of proinsulin biosynthesis in parallel to insulin secretion. Glibenclamide does not regulate insulin production in coordination with stimulated insulin secretion, and consequently depletes islet insulin stores, compromising secretory capacity. Thus, at the level of the beta cell, incretin mimetics have an advantage over sulfonylureas for treatment of type 2 diabetes.

Keywords Exendin 4 Pancreatic islet .

Proinsulin biosynthesis · Sulfonylureas · Sulphonylureas .

Translational control

\author{
Abbreviations \\ CREB cyclic AMP response element binding protein \\ DPP-IV dipeptidyl peptidase IV \\ GLP-1 glucagon-like peptide 1 \\ KRB Krebs-Ringer buffer \\ RPA RNase protection assay
}

\section{Introduction}

The onset of type 2 diabetes is marked by a selective loss of pancreatic beta cells and insulin secretory dysfunction, so that insulin production and secretion no longer compensate for inherent insulin resistance $[1,2]$. Beta cell secretory dysfunction in type 2 diabetes is characterised by a decreased and delayed response to glucose, commonly observed as a loss of first-phase insulin secretion [3]. However, other secretagogues, such as arginine, can induce 
a normal first-phase insulin secretory response in type 2 diabetes [1, 4]. One therapeutic approach for type 2 diabetes has been to use pharmacological reagents that boost endogenous insulin secretion, such as sulfonylureas and glucagon-like peptide 1 (GLP-1) analogues [5, 6]. Ideally, such therapeutic insulin secretagogues should increase insulin production in parallel to insulin secretion, so as to replenish the insulin lost by regulated secretion and maintain optimal beta cell secretory capacity. However, not all pharmacological insulin secretagogues are capable of this.

Sulfonylureas induce insulin secretion by closing ATPsensitive $\mathrm{K}^{+}$channels [7]; this in turn causes the beta cell plasma membrane depolarisation, to open voltage-sensitive L-type $\mathrm{Ca}^{2+}$ channels and instigate a rise in cytosolic $\left[\mathrm{Ca}^{2+}\right] \mathrm{i}$, which is the key signal that triggers insulin exocytosis $[8,9]$. However, sulfonylureas do not stimulate proinsulin biosynthesis [10], and consequently there may be a decrease in the beta cell's intracellular insulin store. Another shortcoming of sulfonylurea therapy is that it can induce insulin secretion independently of circulating glucose concentrations, and this increases the risk of the incidence of hypoglycaemic episodes [5].

GLP-1 analogues mimic the action of the endogenous GLP-1 incretin [6, 11]. Physiologically, GLP-1 acts on the beta cell via specific G $\alpha$ s-protein-coupled GLP-1 receptors to potentiate glucose-induced insulin secretion [12]. Endogenous GLP-1 has a short half-life of $\sim 2 \mathrm{~min}$ in vivo [13], and consequently its biological action is limited. GLP1 is inactivated in vivo by limited proteolysis via a protease called dipeptidyl peptidase IV (DPP-IV) [13]. Long-acting GLP-1 analogue agonists, such as exendin 4 (also known as exenatide and Byetta [14]), are relatively resistant to DPPIV proteolysis, and consequently have a considerably longer half-life in the circulation compared with native GLP-1 [15]. They bind the beta cell GLP-1 receptor with equivalent affinity to native GLP-1 and consequently exhibit effects similar to those of GLP-1 [11]. Like endogenous GLP-1 [16], GLP-1 analogues only promote insulin secretion in a glucose-dependent manner [11], and consequently the risk of hypoglycaemia is lessened when they are used therapeutically [17]. Furthermore, it has been reported that GLP-1 might maintain beta cell insulin secretory capacity by augmenting preproinsulin gene transcription and proinsulin synthesis, coordinately with insulin secretion, in pancreatic beta cell lines [18, 19], and islets from transgenic mouse models [20]. However, this is not particularly well established in normal primary islet beta cells. In this study, we compared the effects of exendin 4 and the sulfonylurea glibenclamide (known as glyburide in the USA and Canada) on the balance between insulin secretion and production in isolated pancreatic islets from normal rats.

\section{Materials and methods}

Materials

For metabolic radiolabelling of islets we used Redivue Pro-mix L- $\left[{ }^{35} \mathrm{~S}\right]$ in vitro cell labelling mix $(37 \mathrm{TBq} / \mathrm{mmol})$ from Amersham Bioscience (Piscataway, NJ, USA), containing $\mathrm{L}-\left[{ }^{35} \mathrm{~S}\right]$ methionine and $\mathrm{L}-\left[{ }^{35} \mathrm{~S}\right]$ cysteine. Redivue uridine $5^{\prime}-\left[\alpha_{-}{ }^{32} \mathrm{P}\right]$ triphosphate $(111 \mathrm{TBq} / \mathrm{mmol})$ was also from Amersham Bioscience. Guinea pig anti-bovine insulin serum was from Sigma-Aldrich (St Louis, MO, USA). Rabbit anti-phospho(Ser133)-CREB (CREB is cyclic AMP response element binding protein) and anti-CREB antibodies were from Cell Signaling Technology (Beverly, MA, USA). Exendin 4 was from American Peptide Company (Sunnyvale, CA, USA). The Direct Protect Lysate RNase protection assay (RPA) kit was from Ambion (Austin, TX, USA). Real-time RT-PCR Taq-Man kit, primers, probes and plates were from Applied Biosystems (Foster City, CA, USA). Glibenclamide and other reagents were from SigmaAldrich unless otherwise stated.

Islet isolation and culture

Islets of Langerhans were isolated from pancreases of male Wistar rats weighing $250 \mathrm{~g}$ (Charles River Laboratories, Wilmington, MA, USA), as described previously [21]. The use and care of the animals was in accordance with the principles and guidelines of the Institutional Animal Care Administrative Committee at the Pacific Northwest Research Institute. For short-term experiments, isolated islets were cultured overnight at $37^{\circ} \mathrm{C}$ in RPMI-1640 containing a normoglycaemic glucose concentration ( $5.6 \mathrm{mmol} / \mathrm{l})$, then preincubated for $1 \mathrm{~h}$ at basal $(2.8 \mathrm{mmol} / \mathrm{l})$ glucose in Krebs-Ringer buffer (KRB), pH 7.4, containing $20 \mathrm{mmol} / 1 \mathrm{HEPES}$ and $0.1 \%(\mathrm{w} / \mathrm{v}) \mathrm{BSA}$, followed by a second 1 -h incubation in $\mathrm{KRB}$ at $2.8-16.7 \mathrm{mmol} / 1$ glucose with or without exendin $4(10 \mathrm{nmol} / \mathrm{l})$ or glibenclamide (1 $\mu \mathrm{mol} / 1$ ), as described previously [10]. For long-term experiments, islets were cultured for $16 \mathrm{~h}$ in RPMI-1640 containing glucose at $2.8-16.7 \mathrm{mmol} / \mathrm{l}$ with or without exendin $4(10 \mathrm{nmol} / \mathrm{l})$ or glibenclamide $(1 \mu \mathrm{mol} / \mathrm{l})$, followed by incubation for $1 \mathrm{~h}$ in $\mathrm{KRB}$ at the same glucose concentration with or without exendin $4(10 \mathrm{nmol} / \mathrm{l})$ or glibenclamide (1 $\mu \mathrm{mol} / \mathrm{l})$ as described previously [10].

Proinsulin biosynthesis and insulin secretion in isolated islets

For short-term experiments, after the second 1-h incubation period, an aliquot of medium was collected for insulin secretion analysis. Then, islets were radiolabelled with the $\left[{ }^{35} \mathrm{~S}\right]$ methionine $/\left[{ }^{35} \mathrm{~S}\right]$ cysteine mix $(3.7 \mathrm{MBq} / 0.1 \mathrm{ml})$ for 
another 30 min under the same conditions, and washed and lysed as described previously [10, 21]. For long-term experiments, after the 16-h incubation period, medium was collected for analysis of insulin secretion. Islets were transferred to KRB containing the same glucose concentration with or without exendin 4 or glibenclamide and incubated for $1 \mathrm{~h}$. Then, an aliquot of medium was also collected for insulin secretion analysis, and islets were radiolabelled with $\left[{ }^{35} \mathrm{~S}\right]$ methionine $/\left[{ }^{35} \mathrm{~S}\right]$ cysteine mix (3.7 MBq/0.1 ml) for an additional $30 \mathrm{~min}$, collected, washed and lysed as described $[10,21]$. The degree of $\left[{ }^{35} \mathrm{~S}\right]$ proinsulin biosynthesis was determined in islet lysates by immunoprecipitation and alkaline-urea PAGE, as described previously $[10,21]$. The $\left[{ }^{35} \mathrm{~S}\right]$ total protein synthesis was analysed by trichloroacetic acid precipitation as described [21]. The fold change in proinsulin biosynthesis was corrected for that of total protein synthesis values, so that the specific effect on proinsulin biosynthesis could be ascertained. Insulin secretion was analysed in the islet incubation medium and intracellular insulin content in islet lysates by RIA (rat insulin RIA kit; Linco Research, St Charles, MO, USA).

RNase protection assay of islet preproinsulin mRNA

After 1 or $16 \mathrm{~h}$ of incubation, levels of preproinsulin mRNA were determined in islet lysates as described previously $[10,22]$. Briefly, RNA was protected using a $\left[{ }^{32} \mathrm{P}\right]$ uridine-labelled antisense RNA fragment corresponding to the coding regions of rat preproinsulin-1 and -2 mRNAs. Unprotected RNA was digested with an RNase cocktail. Protected mRNA was then resolved by gel electrophoresis and analysed by quantitative densitometric scanning of autoradiographs. As a control, $\beta$-actin RPA was performed in parallel to preproinsulin RPA in the same islet lysates. Results are shown as the ratio of preproinsulin mRNA to $\beta$-actin mRNA.

Quantitative real-time RT-PCR analysis of preproinsulin mRNA

Total RNA was isolated from batches of 100 rat islets using the RNeasy mini-kit method (Qiagen, Valencia, CA, USA) and in-column DNase (Qiagen) treatment. Real-time PCR analysis of control samples in the absence of reverse transcriptase yielded no product (data not shown). Fluorescence-based real-time RT-PCR was performed as described [23] using the forward primer 5'-GCCCAGGCTTTTGT CAAACA-3', the reverse primer 5'-CTCCCCACACAC CAGGTAGAG-3' and TaqMan TAMRA labelled probe 6FAM-AGCTTCCACCAAGTGAGAACCACAAAGGTTAMRA from the rat insulin II cDNA sequence. As a control, $\beta$-actin real-time RT-PCR was performed in parallel in the same islet RNA preparations. $\beta$-Actin primers and probe were: forward primer $5^{\prime}$-ACGAGGCC CAGAGCAAGA-3'; reverse primer 5'-TTGGTTACAA TGCCGTGTTCA-3'; probe 6FAM-TGGGTCCTCCACTT CACGGCG-TAMRA. Results are shown as the ratio of preproinsulin to $\beta$-actin mRNA.

Immunoblotting analysis of CREB phosphorylation

After the indicated incubation time, CREB phosphorylation was analysed in islet lysates prepared from batches of 100 islets, as described previously [24]. Nitrocellulose membranes were first immunoblotted for phospho-CREB $(1: 1,000)$, then stripped by incubation for $30 \mathrm{~min}$ at $50^{\circ} \mathrm{C}$ in $62.5 \mathrm{mmol} / 1$ Tris, $\mathrm{pH} 6.8,2 \% \mathrm{SDS}, 0.1 \mathrm{~mol} / 1 \beta$-mercaptoethanol, and subsequently immunoblotted for total CREB $(1: 1,000)$.

\section{Statistical analysis}

Results are presented as mean $\pm \mathrm{SEM}$, with $n$ referring to the number of independent experiments. Statistically significant differences between groups were analysed using the Student's $t$-test for unpaired samples. A $p$ value $<0.05$ was considered to indicate a significant difference.

\section{Results}

Effect of exendin 4 and glibenclamide on islet preproinsulin mRNA levels

After a 1-h short-term incubation, neither glucose, exendin 4 nor glibenclamide affected islet preproinsulin mRNA levels (Fig. 1a). In the long-term incubations (16 h), glucose (at $\geq 5.6 \mathrm{mmol} / \mathrm{l}$ ) increased preproinsulin mRNA levels in isolated rat islets; the increase reached a maximum of $\sim 4$-fold at $\geq 8 \mathrm{mmol} / \mathrm{l}$ glucose relative to control $\beta$-actin mRNA levels (Fig. 1b), similar to previous observations $[10,25]$. Neither exendin 4 nor glibenclamide significantly altered the long-term effect of glucose on preproinsulin mRNA levels in primary rat islets (Fig. 1b). Control $\beta$-actin mRNA levels were not significantly affected by glucose, exendin 4 or glibenclamide in both 1-h and 16-h experiments (data not shown). Preproinsulin mRNA levels were also determined by real time RT-PCR in islets incubated between 2.8 and $16.7 \mathrm{mmol} / \mathrm{l}$ glucose with or without exendin $4(10 \mathrm{nmol} / \mathrm{l})$ for $16 \mathrm{~h}$. Similar results to that of the RPA were found, in that there was no additional effect of exendin 4 on glucose-induced preproinsulin mRNA expression (Fig. 1c).

Although exendin 4 did not appear to augment glucoseinduced preproinsulin mRNA levels in rat islets, it 
a
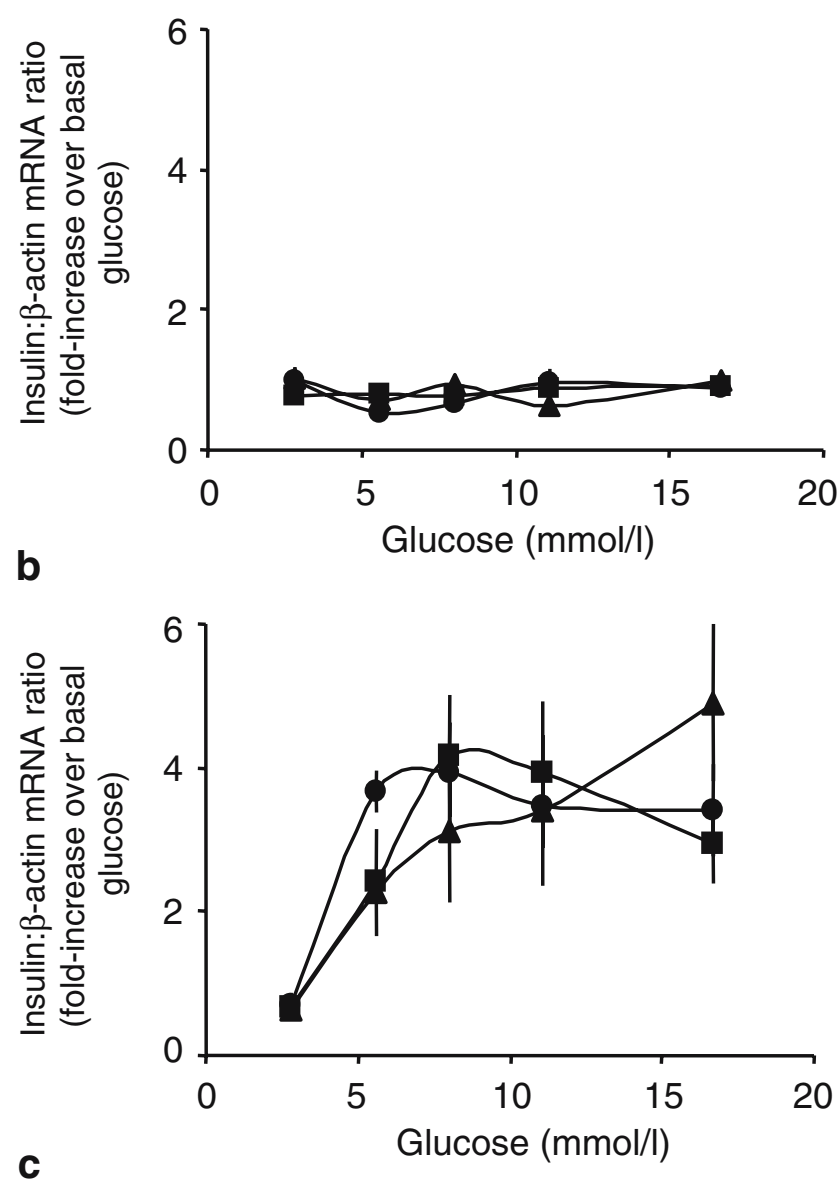

C

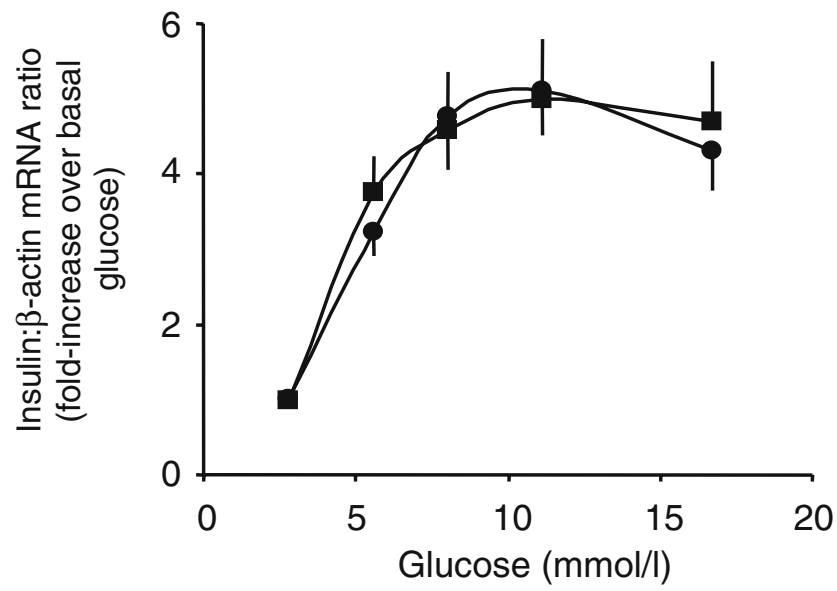

Fig. 1 Effect of exendin 4 and glibenclamide on preproinsulin mRNA levels in isolated rat islets. Islet preproinsulin mRNA levels were determined, as described in Materials and methods, in isolated rat islets incubated for $1 \mathrm{~h}$ (a) or $16 \mathrm{~h}(\mathbf{b}, \mathbf{c})$, over a range of glucose concentrations, alone (circles) or in the additional presence of $10 \mathrm{nmol} / 1$ exendin 4 (squares) or $1 \mu \mathrm{mol} / 1$ glibenclamide (triangles). a, b Densitometric quantification of gel autoradiographs. c Real-time RT-PCR analysis of glucose and exendin 4 effects. Collective data are presented as the ratio of preproinsulin: $\beta$-actin mRNA as mean \pm SEM fold stimulation over basal $(2.8 \mathrm{mmol} / \mathrm{l})$ glucose $(n \geq 3)$ nonetheless increased the phosphorylation of the transcription factor CREB (Fig. 2). Stimulatory glucose $(16.7 \mathrm{mmol} / \mathrm{l})$ transiently increased CREB phosphorylation at Ser133 after 5 min exposure (2.1 \pm 0.2 -fold, $p<0.05$ vs time zero), but a basal CREB phosphorylation state returned within $1 \mathrm{~h}$ (Fig. 2). Exendin $4(10 \mathrm{nmol} / \mathrm{l})$ significantly potentiated CREB phosphorylation induced by $16.7 \mathrm{mmol} / 1$ glucose, which peaked at $5 \mathrm{~min}$ (3.8 \pm 0.6 -fold over basal [time zero], $p<0.05$ vs glucose alone) and was sustained up to $2 \mathrm{~h}$ thereafter, although diminishingly so. After $16 \mathrm{~h}$ of incubation exendin 4 was unable to stimulate CREB phosphorylation even when islets were allowed to recover at basal $(2.8 \mathrm{mmol} / \mathrm{l})$ glucose for $1 \mathrm{~h}$ and then restimulated for $1 \mathrm{~h}$ with a fresh dose of high glucose $(16.7 \mathrm{mmol} / \mathrm{l})$ and $10 \mathrm{nmol} / 1$ exendin 4 (Fig. 2). Total CREB levels did not notably change (data not shown), indicating that this was a specific effect of glucose/exendin 4 on CREB phosphorylation. These data indicate that isolated islets were responsive to exendin 4, despite the lack of effect of exendin 4 on preproinsulin mRNA levels (Fig. 1).

Effect of exendin 4 and glibenclamide on glucose-induced proinsulin biosynthesis and total protein synthesis in isolated rat islets

In the short term $(1 \mathrm{~h})$, glucose $(\geq 5.6 \mathrm{mmol} / \mathrm{l})$ specifically stimulated proinsulin biosynthesis up to a maximum of 6fold at $16.7 \mathrm{mmol} / \mathrm{l}$ glucose (Fig. 3a), as previously observed [21]. Exendin $4(10 \mathrm{nmol} / \mathrm{l})$ had no effect on total protein synthesis in rat islets (Fig. 4a), but significantly

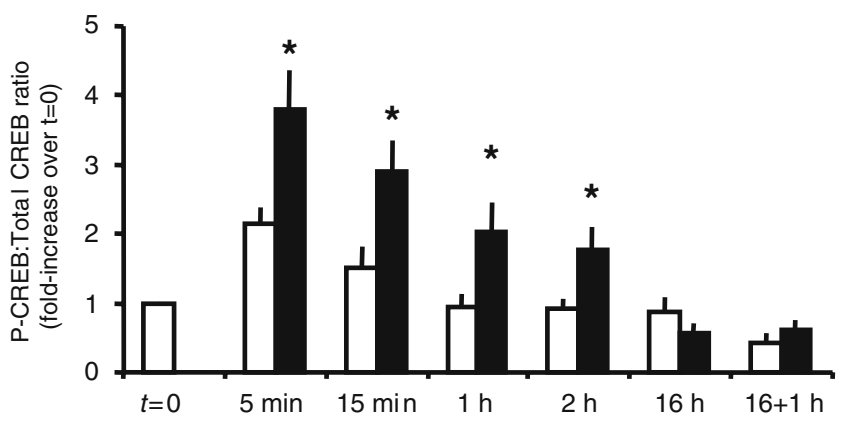

Fig. 2 Time course of effects of glucose and exendin 4 on CREB phosphorylation in isolated rat islets. Phospho-CREB (P-CREB) levels in islets treated with $16.7 \mathrm{mmol} / \mathrm{l}$ glucose alone (open bars) or in the additional presence of $10 \mathrm{nmol} / 1$ exendin 4 (black bars) were analysed as described in Materials and methods. Collective data on the fold increase in P-CREB relative to total CREB compared with time zero $(t=0)$ are shown as means $\pm \operatorname{SEM}(n \geq 6) .{ }^{*} p<0.05$ vs the equivalent observation for glucose alone. The $16+1 \mathrm{~h}$ observation represents islets incubated for $16 \mathrm{~h}$ at $16.7 \mathrm{mmol} / \mathrm{l}$ glucose with or without exendin 4 , followed by $1 \mathrm{~h}$ of recovery at basal $(2.8 \mathrm{mmol} / \mathrm{l})$ glucose and then stimulation for $1 \mathrm{~h}$ at $16.7 \mathrm{mmol} / 1$ glucose with or without exendin 4 
Fig. 3 Effect of exendin 4 and glibenclamide on glucose-induced proinsulin biosynthesis in isolated rat islets. Proinsulin biosynthesis was determined, as described in Materials and methods, in isolated rat islets incubated for $1 \mathrm{~h} \mathrm{(a)}$ or $16 \mathrm{~h} \mathrm{(b)}$ over a range of glucose concentrations only (circles) or in the additional presence of $10 \mathrm{nmol} / 1$ exendin 4 (squares) or $1 \mu \mathrm{mol} / 1$ glibenclamide (triangles). Representative gel phosphorimages and densitometric quantifications of these are shown. Collective data on the fold increase in proinsulin biosynthesis over basal $(2.8 \mathrm{mmol} / \mathrm{l})$ glucose alone are shown as mean \pm SEM $(n \geq 6)$ ${ }^{*} p<0.05,{ }^{*} p<0.01$ vs the equivalent glucose-alone observation. c Effect of extracellular $\mathrm{Ca}^{2+}$ depletion on the 1-h glibenclamide regulation of proinsulin biosynthesis. Representative phosphorimages are shown from three independent experiments a
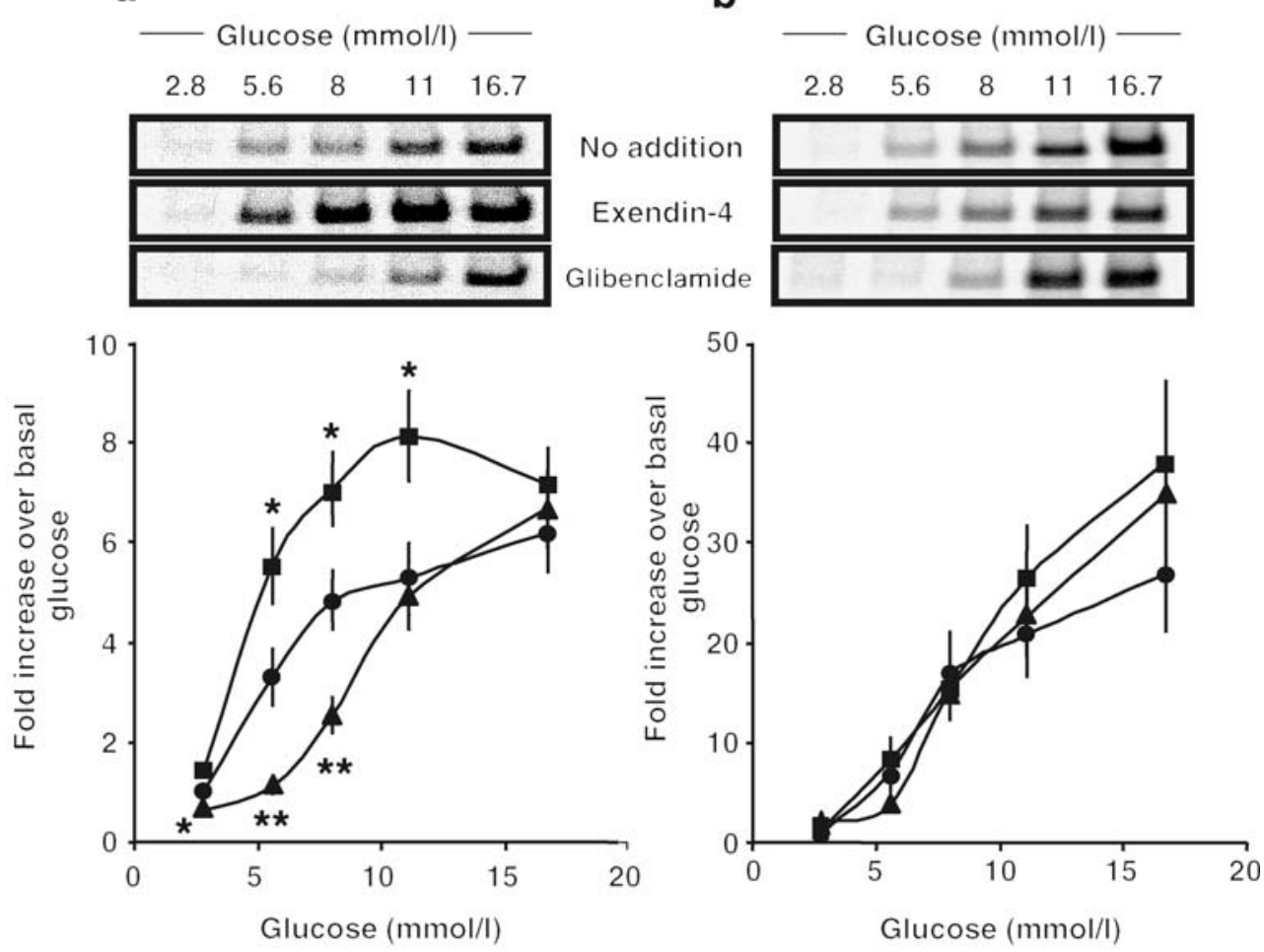

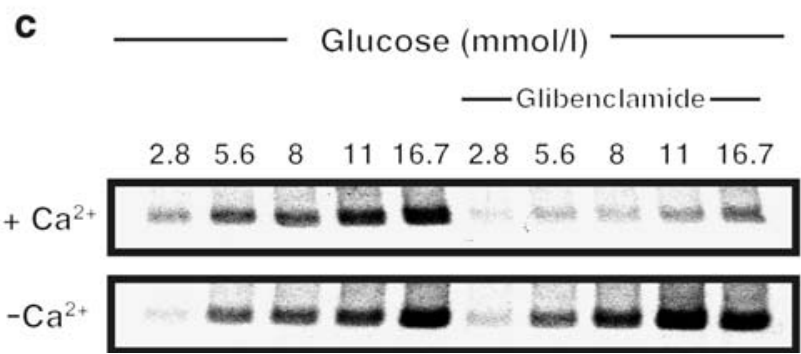

$(p<0.05)$ potentiated glucose-induced proinsulin biosynthesis at glucose concentrations of 5.6-11 mmol/1 (Fig. 3a). In contrast, glibenclamide ( $1 \mu \mathrm{mol} / \mathrm{l})$ did not increase proinsulin biosynthesis at any glucose concentration. On the contrary, glibenclamide significantly decreased proinsulin biosynthesis 2 - to 3 -fold $(p<0.05)$ at glucose concentrations between 2.8 and $8 \mathrm{mmol} / \mathrm{l}$ (Fig. 3a). However, this inhibitory effect was not specific to proinsulin biosynthesis, since glibenclamide similarly decreased total protein synthesis at the same glucose concentrations (Fig. 4a). Uptake of extracellular $\mathrm{Ca}^{2+}$ by the beta cell is necessary for glucose- and glibenclamide-induced insulin secretion from isolated islets, but is not required for glucose-induced proinsulin biosynthesis [26]. Indeed, $\mathrm{Ca}^{2+}$ depletion from the islet incubation medium tends to increase total protein synthesis $[10,27]$, and increased cytosolic $\left[\mathrm{Ca}^{2+}\right] \mathrm{i}$ has a negative effect on general protein synthesis translation [28]. Accordingly, the absence of $\mathrm{Ca}^{2+}$ in the extracellular medium prevented the inhibition of proinsulin biosynthesis by glibenclamide (Fig. 3c), in parallel with a recovery of total protein synthesis (data not shown).

For long-term $(16 \mathrm{~h})$ glucose regulation of proinsulin biosynthesis, there was a more potent effect than that observed for the shorter 1-h incubation period: $27 \pm 6$-fold vs $6.2 \pm 0.8$-fold increase at $16.7 \mathrm{mmol} / \mathrm{l}$ above basal (2.8 mmol/l) glucose (Fig. 3b). This approximate 4-fold rise was probably a consequence of the parallel glucoseinduced increase in preproinsulin mRNA levels (Fig. 1b), as described previously [10]. In contrast to the short-term $(1 \mathrm{~h})$ effect (Fig. 3a), in the long term (16 h) exendin 4 caused only a slight increase in proinsulin biosynthesis above that caused by glucose (Fig. 3b), but this was not statistically significant. This was probably a result of desensitisation/downregulation of the GLP-1 signal transduction pathway by prolonged exposure to exendin 4 in vitro [29], and was consistent with the lack of an effect of 

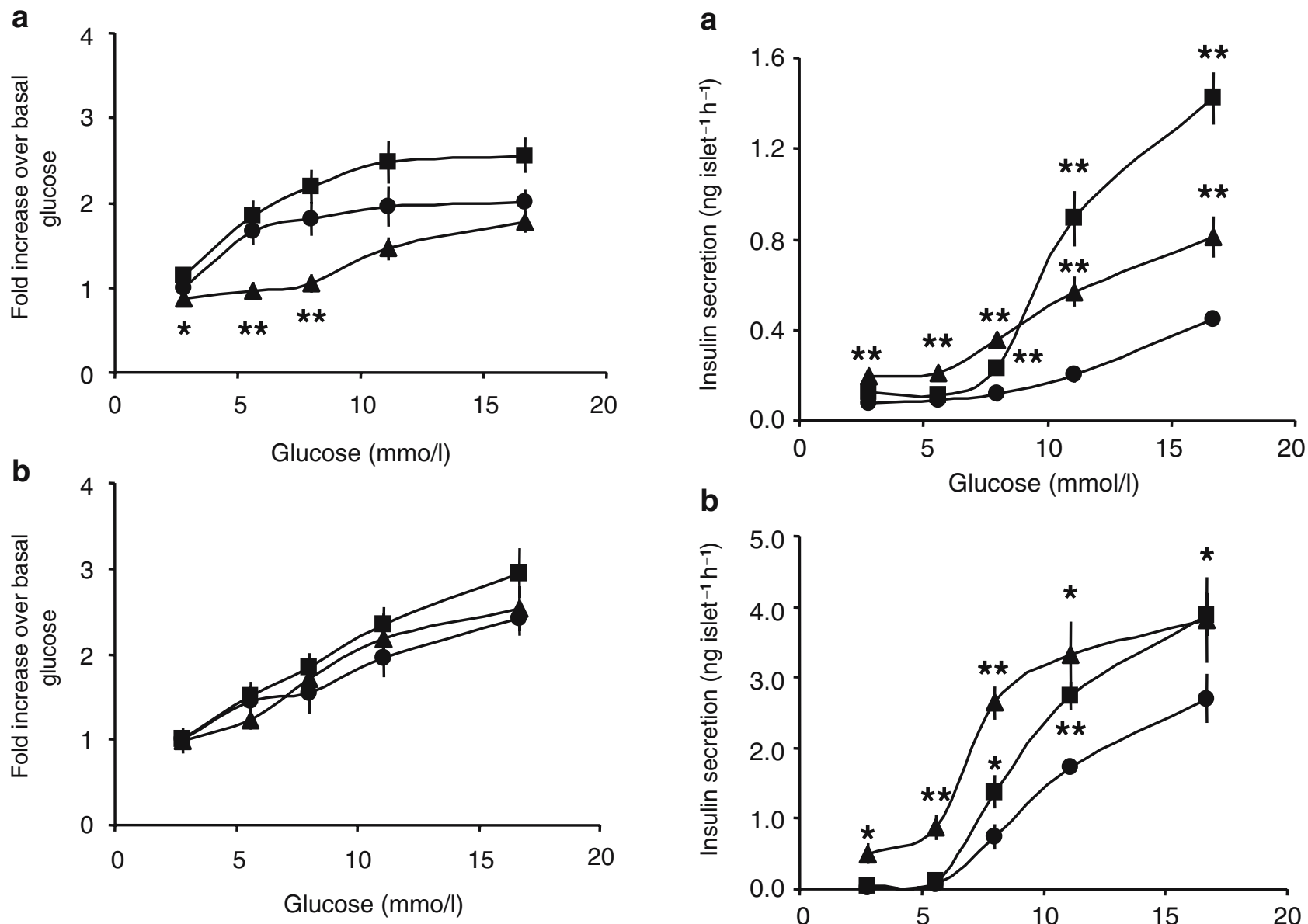

Fig. 4 Effect of exendin 4 and glibenclamide on total protein synthesis in isolated rat islets. Total protein synthesis was determined, as described in Materials and methods, in isolated rat islets incubated for $1 \mathrm{~h} \mathrm{(a)} \mathrm{or} 16 \mathrm{~h} \mathrm{(b)} \mathrm{over} \mathrm{a} \mathrm{range} \mathrm{of} \mathrm{concentrations} \mathrm{of} \mathrm{glucose} \mathrm{only}$ (circles) or in the additional presence of $10 \mathrm{nmol} / 1$ exendin 4 (squares) or $1 \mu \mathrm{mol} / 1$ glibenclamide (triangles). Collective data on the fold increase in general protein synthesis over basal $(2.8 \mathrm{mmol} / \mathrm{l})$ glucose alone are shown as mean \pm SEM $(n \geq 6) .{ }^{*} p<0.05,{ }^{*} p<0.01$ for glibenclamide vs equivalent glucose-alone observation

exendin 4 on CREB phosphorylation observed after a long exposure $(16 \mathrm{~h}$ ) to exendin 4 (Fig. 2). Glibenclamide did not significantly affect proinsulin biosynthesis at any glucose concentration during the 16 -h incubation period, except at $2.8 \mathrm{mmol} / 1$ glucose, when a small (2.0 \pm 0.3 -fold $)$ increase over glucose alone $(p<0.05)$ was observed (Fig. 3b), as shown previously [10]. Neither exendin 4 nor glibenclamide modified the effect of glucose on total protein synthesis during this $16-\mathrm{h}$ incubation (Fig. $4 \mathrm{~b}$ ).

Effect of exendin 4 and glibenclamide on insulin secretion and islet insulin content

Insulin secretion was assessed in the same isolated rat islets as those used for studying proinsulin biosynthesis. In the short term $(1 \mathrm{~h})$, exendin $4(10 \mathrm{nmol} / \mathrm{l})$ significantly poten-
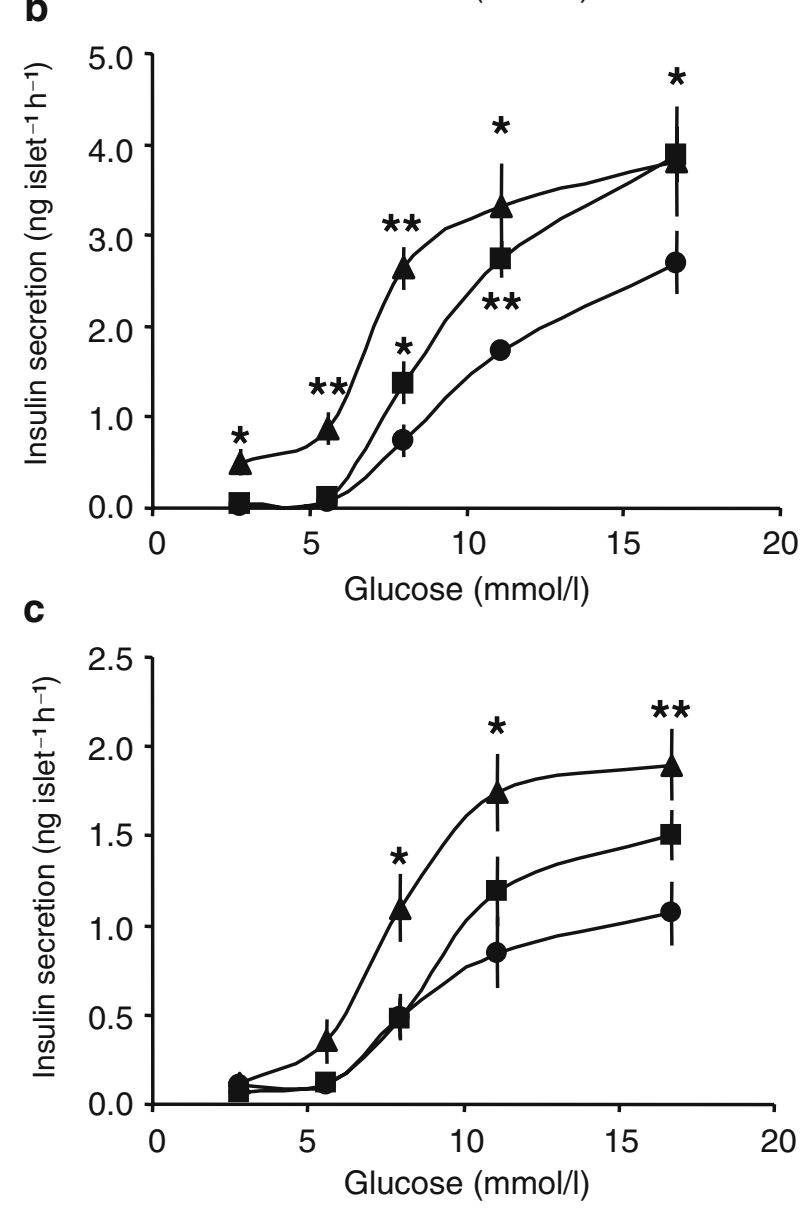

Fig. 5 Effect of exendin 4 and glibenclamide on glucose-induced insulin secretion from isolated rat islets. Insulin secretion from isolated rat islets was determined, as described in Materials and methods, in isolated rat islets incubated for $1 \mathrm{~h} \mathrm{(a),} 16 \mathrm{~h} \mathrm{(b)}$ and 1 additional hour after the 16-h incubation period (c), over a range of glucose concentrations, in the absence (circles) or in the additional presence of $10 \mathrm{nmol} / 1$ exendin 4 (squares) or $1 \mu \mathrm{mol} / 1$ glibenclamide (triangles). Collective data on insulin secretion rates are shown as mean \pm SEM $(n \geq 6) . * p<0.05, * * p<0.01$ vs equivalent glucose-alone observation 
a

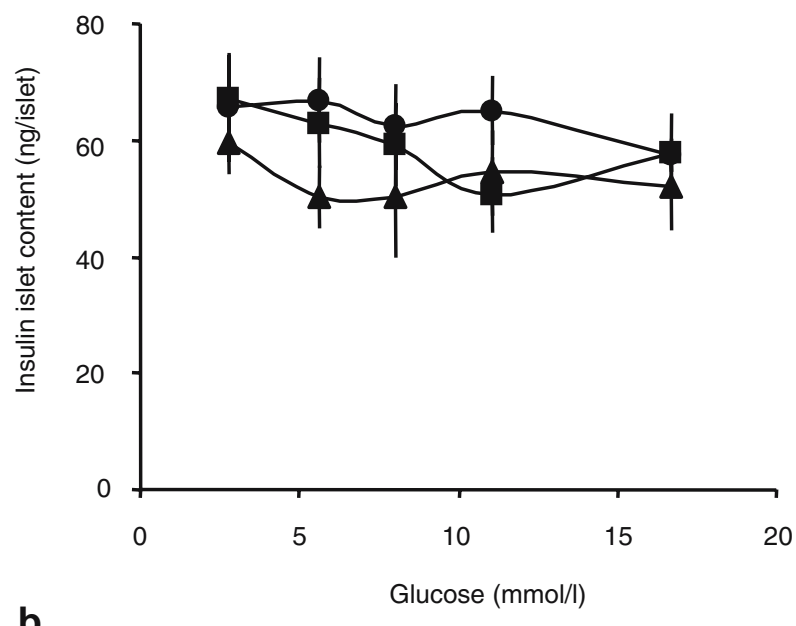

b

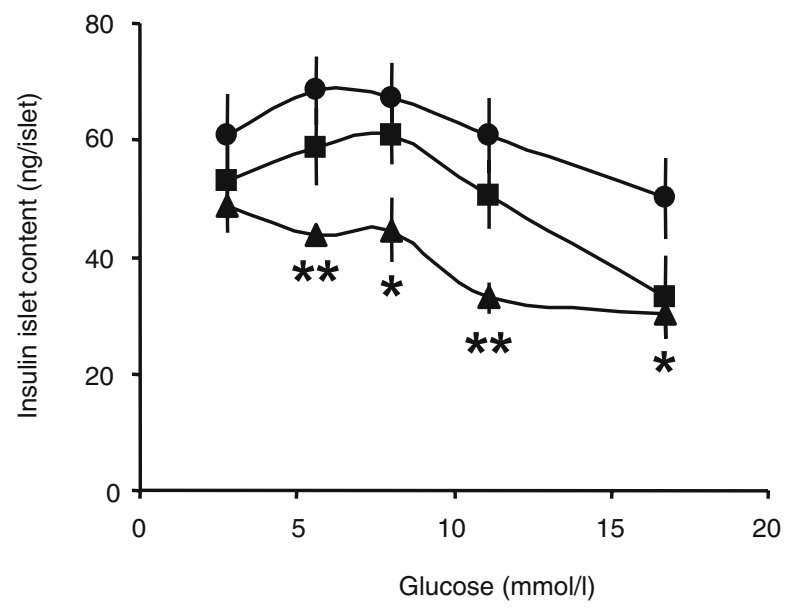

Fig. 6 Effects of exendin 4 and glibenclamide on the insulin content of isolated rat islets. Residual islet insulin content was determined, as described in Materials and methods, in the same isolated rat islets examined for proinsulin biosynthesis, total protein synthesis and insulin secretion (Figs. 3, 4, 5) that were incubated for $1 \mathrm{~h}(\mathbf{a})$ or $16 \mathrm{~h}$ (b), over a range of glucose concentrations, in the absence (circles) or the additional presence of $10 \mathrm{nmol} / 1$ exendin 4 (squares) or $1 \mu \mathrm{mol} / 1$ glibenclamide (triangles). Collective data on islet residual insulin content are shown as mean $\pm \operatorname{SEM}(n \geq 6)$, where significant differences $\left(* p<0.05,{ }^{* *} p<0.01\right)$ compared with the equivalent glucose-alone observation are indicated

tiated glucose-induced insulin secretion at $\geq 8 \mathrm{mmol} / 1$ glucose $(p<0.01$; Fig. 5a). In contrast, glibenclamide $(1 \mu \mathrm{mol} / \mathrm{l})$ significantly increased insulin secretion at basal $(2.8 \mathrm{mmol} / \mathrm{l})$ and $5.6 \mathrm{mmol} / \mathrm{l}$ glucose concentrations $(p<0.01$; Fig. 5a), indicating its glucose-independent secretagogue effect $[10,30]$. At $\geq 8 \mathrm{mmol} / \mathrm{l}$ glucose, glibenclamide potentiated glucose-induced insulin secretion approximately 2.5 -fold $(p<0.01$; Fig. 5a). However, this potentiation of insulin secretion by glibenclamide at higher glucose concentrations ( 11 and $16.7 \mathrm{mmol} / \mathrm{l})$ was nonetheless smaller than that induced by exendin 4 (Fig. 5a). The islet insulin content did not change significantly at any glucose concentration in the presence or absence of glibenclamide or exendin 4 in the short-term $(1 \mathrm{~h})$ incubation (Fig. 6a). This was reflective of only a small fraction of the intracellular insulin stores being secreted per hour, which even under maximal stimulatory conditions of $16.7 \mathrm{mmol} / \mathrm{l}$ glucose plus exendin 4 was only $2.6 \pm 0.3 \%$ per hour of the total insulin content.

Chronic $(16 \mathrm{~h})$ exposure of isolated islets to glucose resulted in a larger increase in the rate of insulin secretion than that observed during short-term $\left(\begin{array}{ll}1 & \mathrm{~h}\end{array}\right)$ incubation at $\geq 8 \mathrm{mmol} / 1$ glucose (Fig. $5 \mathrm{~b}$ vs a). Exendin 4 $(10 \mathrm{nmol} / \mathrm{l})$ significantly potentiated insulin secretion from isolated islets incubated for $16 \mathrm{~h}$ only at stimulatory glucose concentrations ( $\geq 8 \mathrm{mmol} / 1, p<0.05$; Fig. 5b). However, this exendin 4 potentiation effect was proportionally less than that observed for the short-term $(1 \mathrm{~h})$ incubation period (Fig. 5a), and even more reduced when a fresh dose of exendin $4(10 \mathrm{nmol} / \mathrm{l})$ was added and the islets were incubated for another $1 \mathrm{~h}$ in addition to the 16-h period (Fig. 5c). This was probably indicative of partial desensitisation of exendin 4/GLP-1 signalling in long-term in vitro incubations [29]. Glibenclamide ( $1 \mu \mathrm{mol} / \mathrm{l})$ significantly induced insulin secretion at every glucose concentration during the 16-h incubation period $(p<0.05$; Fig. $5 \mathrm{~b})$. At basal $(2.8 \mathrm{mmol} / \mathrm{l})$ and $5.6 \mathrm{mmol} / \mathrm{l}$ glucose, glibenclamide-induced insulin secretion was $>6$-fold greater in the long-term $(16 \mathrm{~h})$ than in the short-term $(1 \mathrm{~h})$ incubation. Glibenclamide also significantly increased insulin secretion (2-fold, $p<0.05$ ), especially at glucose concentrations $\geq 8 \mathrm{mmol} / \mathrm{l}$, when an additional 1 -h incubation period with fresh glibenclamide $(1 \mu \mathrm{mol} / \mathrm{l})$ was performed after the 16-h incubation (Fig. 5c). After $16 \mathrm{~h}$ of incubation, glibenclamide $(1 \mu \mathrm{mol} / \mathrm{l})$ significantly decreased islet insulin content, by approximately $40 \%(p<0.05)$, at glucose concentrations greater than $2.8 \mathrm{mmol} / \mathrm{l}$ compared with control islets (Fig. 6b). In contrast, exendin $4(10 \mathrm{nmol} / \mathrm{l})$ had only a marginal effect in decreasing islet insulin content compared with that of glibenclamide at $5-11 \mathrm{mmol} / 1$ glucose concentrations, and its effect was not statistically significant compared with that of glucose alone (Fig. 6b). A more marked decrease in islet insulin content in the presence of exendin 4, similar to that seen with glibenclamide, was observed at $16.7 \mathrm{mmol} / 1$ glucose, but this nonetheless did not reach statistical significance (Fig. 6b).

\section{Discussion}

In order to maintain optimal intracellular insulin content, when insulin is secreted by the beta cell a parallel increase 
in insulin production is required to replenish the insulin stores. Thus, when insulin secretagogues are used for the treatment of type 2 diabetes, it is preferable that there is a coordinated upregulation of insulin production to maintain the beta cell insulin secretory capacity. In this in vitro study, it was found that the long-acting GLP-1 analogue exendin 4 better maintained islet beta cell insulin stores, because it increased proinsulin biosynthesis coordinately with insulin secretion. Exendin 4 potentiated glucose-induced proinsulin biosynthesis without altering preproinsulin mRNA levels, especially in the short term, and consequently was predominately regulating proinsulin biosynthesis at the translational level. The specific glucose-induced control of proinsulin biosynthesis mediated at the translational level is well established [10,21, 22], but, to our knowledge, this is the first demonstration that GLP-1 analogues are capable of enhancing translational control of proinsulin synthesis in primary beta cells. This is consistent with previous observations, in that reagents (including glucagon, theophylline, caffeine, methylxanthines and dibutyryl cyclic AMP) which, like GLP-1/exendin 4 [11, 18], also increase intracellular cyclic AMP levels in islet beta cells, potentiate the glucose-induced control of proinsulin synthesis at the translational level [31, 32].

No effect of exendin 4 on regulating preproinsulin mRNA levels above the effect of glucose in primary rat islet beta cells was found. This is in contrast to previous observations in pancreatic beta cell lines, in which GLP-1 increased preproinsulin mRNA levels [18, 19, 33], but these are dedifferentiated cells and do not always reflect the functional characteristics of primary beta cells. Both GLP-1 and exendin 4 have been shown to augment preproinsulin mRNA levels in vivo [20,34], but this could be reflective of increased beta cell mass [35]. It has been indicated previously that exendin 4 can increase preproinsulin mRNA levels in murine islets in vitro via a mechanism dependent on pdx-1 [20], but the lack of effect of exendin 4 on preproinsulin mRNA found in this study suggests that there may be a species difference between wild-type rats and certain transgenic mice. However, it should be considered that preproinsulin gene expression in pancreatic beta cells is not especially regulated by elevations in [cyclic AMP]i and that the cyclic AMP response element (CRE) in the preproinsulin gene promoter is relatively silent $[24,36$, 37]. Consequently, when GLP-1/exendin 4 is found to increase preproinsulin mRNA levels in beta cells they are probably operating via secondary effects. Nonetheless, the lack of an effect of exendin 4 on preproinsulin mRNA levels in isolated rat islets emphasises that GLP-1/exendin 4 principally regulates proinsulin biosynthesis at the translational level.

It should also be noted that, with longer-term exposure of exendin 4 to isolated rat islets, the potentiation of glucose-induced proinsulin biosynthesis was much reduced, most likely because of GLP-1 receptor signalling desensitisation in vitro, which is consistent with previous observations [29]. The in vitro effects of exendin 4 on isolated rat islets were relatively transient. For example, exendin 4 did not significantly increase CREB phosphorylation beyond $2 \mathrm{~h}$, and was ineffective in mediating any further CREB phosphorylation after $16 \mathrm{~h}$ chronic exposure to exendin 4 . Such desensitisation to chronic $(16 \mathrm{~h})$ exposure to exendin 4 was also found, in that the potentiation of glucose-induced proinsulin biosynthesis at the translational level (Fig. 3) and the ability to enhance glucose-stimulated insulin release was much reduced (Fig. 5). It is possible that this chronic GLP-1/exendin 4 desensitisation could also contribute to the lack of effect of exendin 4 in regulating preproinsulin mRNA levels in rat islets. However, it is currently unclear whether the exendin 4 desensitisation observed here in vitro can be extended to islet beta cell function in vivo. Given the long-term effectiveness of long-acting GLP-1 analogues in improving insulin secretion and sensitivity in type 2 diabetes [38], it seems that any desensitisation at the level of islet beta cells in vivo is relatively moot. Moreover, even if there is a degree of beta cell desensitisation to chronic exposure to GLP-1 analogues in vivo, one must consider additional therapeutic benefits of this class of reagent, such as satiety and weight loss [17], which would also contribute to the alleviation of the type 2 diabetic state.

In contrast to exendin 4, the sulfonylurea glibenclamide had no effect on increasing proinsulin biosynthesis translation at either basal or stimulatory glucose concentrations, in agreement with previous studies [10, 39], despite promoting insulin secretion independently of glucose concentration. Consequently, in islets chronically treated with sulfonylureas, an imbalance can arise between the rates of insulin secretion and proinsulin biosynthesis. This imbalance was exaggerated at basal and intermediate glucose concentrations (3-8 $\mathrm{mmol} / \mathrm{l})$, at which normal glucose regulation of proinsulin biosynthesis was compromised by glibenclamide, probably as a result of cytosolic $\left[\mathrm{Ca}^{2+}\right] \mathrm{i}$ levels becoming too high. Thus, the increase in insulin secretion instigated by long-term exposure to glibenclamide cannot be replenished, which consequently reduces islet insulin content and eventually undermines the insulinsecretory capacity of the beta cell. Because exendin 4 potentiated glucose-induced proinsulin biosynthesis and insulin secretion in parallel, intracellular islet beta cell insulin stores were better preserved. Thus, from a beta cell perspective alone, long-acting GLP-1 analogues, and perhaps even DPP-IV inhibitors, which prolong the action of endogenous GLP-1 [40], are more beneficial than sulfonylureas for the treatment of type 2 diabetes by 
better maintaining the insulin secretory capacity of islet beta cells.

Acknowledgement This work was supported by a grant from the US National Institutes of Health (DK 50610).

Duality of interest None of the authors involved in this study had any duality of interest.

\section{References}

1. Leahy JL (1990) Natural history of $\beta$-cell dysfunction in NIDDM. Diabetes Care 13:992-1010

2. Rhodes CJ (2005) Type 2 diabetes - a matter of beta-cell life and death? Science 307:380-384

3. Perley MJ, Kipnis DM (1967) Plasma insulin responses to oral and intravenous glucose: studies in normal and diabetic subjects. J Clin Invest 46:1954-1962

4. Ward WK, Beard JC, Porte D Jr (1986) Clinical aspects of islet Bcell function in non-insulin-dependent diabetes mellitus. Diabetes Metab Rev 2:297-313

5. Henquin JC (1992) The fiftieth anniversary of hypoglycaemic sulphonamides. How did the mother compound work? Diabetologia 35:907-912

6. Deacon CF (2004) Therapeutic strategies based on glucagon-like peptide 1. Diabetes 53:2181-2189

7. Sturgess NC, Ashford ML, Cook DL, Hales CN (1985) The sulphonylurea receptor may be an ATP-sensitive potassium channel. Lancet 31:474-475

8. Ashcroft FM, Rorsman P (1989) Electrophysiology of the pancreatic beta-cell. Prog Biophys Mol Biol 54:87-143

9. Wollheim CB, Lang J, Regazzi R (1996) The exocytotic process of insulin secretion and its regulation by $\mathrm{Ca}^{2+}$ and G-proteins. Diabetes Rev 4:276-297

10. Wicksteed B, Alarcon C, Briaud I, Lingohr MK, Rhodes CJ (2003) Glucose-induced translational control of proinsulin biosynthesis is proportional to preproinsulin mRNA levels in islet beta-cells but not regulated via a positive feedback of secreted insulin. J Biol Chem 278:42080-42090

11. Goke R, Fehmann HC, Linn T et al (1993) Exendin 4 is a high potency agonist and truncated exendin-(9-39)-amide an antagonist at the glucagon-like peptide 1-(7-36)-amide receptor of insulinsecreting beta-cells. J Biol Chem 268:19650-19655

12. Thorens B (1992) Expression cloning of the pancreatic beta cell receptor for the gluco-incretin hormone glucagon-like peptide 1 . Proc Natl Acad Sci USA 89:8641-8645

13. Kieffer TJ, McIntosh CH, Pederson RA (1995) Degradation of glucose-dependent insulinotropic polypeptide and truncated glucagon-like peptide 1 in vitro and in vivo by dipeptidyl peptidase IV. Endocrinology 136:3585-3596

14. Exenatide (Byetta) for type 2 diabetes (2005) Med Lett Drugs Ther 47:45-46

15. Edwards CM, Stanley SA, Davis R et al (2001) Exendin 4 reduces fasting and postprandial glucose and decreases energy intake in healthy volunteers. Am J Physiol Endocrinol Metab 281:E155-E161

16. Siegel EG, Schulze A, Schmidt WE, Creutzfeldt W (1992) Comparison of the effect of GIP and GLP-1 (7-36amide) on insulin release from rat pancreatic islets. Eur J Clin Invest 22: 154-157

17. Buse JB, Henry RR, Han J et al (2004) Effect of exenatide (exendin 4) on glycemic control over 30 weeks in sulfonylureatreated patients with type 2 diabetes. Diabetes Care 27: $2628-2635$
18. Drucker DJ, Philippe J, Mojsov S, Chick WL, Habener JF (1987) Glucagon-like peptide I stimulates insulin gene expression and increases cyclic AMP levels in a rat islet cell line. Proc Natl Acad Sci USA 84:3434-3438

19. Fehmann HC, Habener JF (1992) Insulinotropic hormone glucagon-like peptide-I (7-37) stimulation of proinsulin gene expression and proinsulin biosynthesis in insulinoma $\beta \mathrm{TC}-1$ cells. Endocrinology 130:159-166

20. Li Y, Cao X, Li LX, Brubaker PL, Edlund H, Drucker DJ (2005) $\beta$-Cell Pdx1 expression is essential for the glucoregulatory, proliferative, and cytoprotective actions of glucagon-like peptide 1 . Diabetes 54:482-491

21. Alarcon C, Lincoln B, Rhodes CJ (1993) The biosynthesis of the subtilisin-related proprotein convertase PC3, but not that of the PC2 convertase, is regulated by glucose in parallel to proinsulin biosynthesis in rat pancreatic islets. J Biol Chem 268:4276-4280

22. Wicksteed B, Herbert TP, Alarcon C, Lingohr MK, Moss LG, Rhodes CJ (2001) Cooperativity between the preproinsulin mRNA untranslated regions is necessary for glucose-stimulated translation. J Biol Chem 276:22553-22558

23. Tran PO, Gleason CE, Poitout V, Robertson RP (1999) Prostaglandin $\mathrm{E}(2)$ mediates inhibition of insulin secretion by interleukin-1 $\beta$. J Biol Chem 274:31245-31248

24. Schuppin GC, Rhodes CJ (1996) Specific coordinated regulation of PC3 and PC2 gene expression with that of preproinsulin in insulin-producing $\beta$ TC3 cells. Biochem J 313:259-268

25. Nielsen DA, Welsh M, Casadaban MJ, Steiner DF (1985) Control of insulin gene expression in pancreatic beta-cells and in an insulin-producing cell line, RIN-5F cells. I. Effects of glucose and cyclic AMP on the transcription of insulin mRNA. J Biol Chem 260:13585-13589

26. Rhodes CJ (2000) Processing of the insulin molecule. In: LeRoith D, Olefsky JM (eds) Diabetes mellitus: a fundamental and clinical text. 2nd edn. Lippincott Williams \& Wilkins, Philadelphia, pp 20-38

27. Alarcon C, Wicksteed B, Prentki M, Corkey BE, Rhodes CJ (2002) Succinate is a preferential metabolic stimulus-coupling signal for glucose-induced proinsulin biosynthesis translation. Diabetes 51:2496-2504

28. Nairn A, Palfrey HC (1996) Regulation of protein synthesis by calcium. In: Hershey JWB, Mathews MB, Sonenberg N (eds) Translational control. Cold Spring Harbor Laboratory Press, Cold Spring Harbor, NY, pp 295-318

29. Baggio LL, Kim JG, Drucker DJ (2004) Chronic exposure to GLP-1R agonists promotes homologous GLP-1 receptor desensitization in vitro but does not attenuate GLP-1Rdependent glucose homeostasis in vivo. Diabetes 53 (Suppl 3): S205-S214

30. Gorus FK, Schuit FC, In't Veld PA, Gepts W, Pipeleers DG (1988) Interaction of sulfonylureas with pancreatic beta-cells. A study with glyburide. Diabetes 37:1090-1095

31. Schatz H, Maier V, Hinz M, Nierle C, Pfeiffer EF (1973) Stimulation of H-3-leucine incorporation into the proinsulin and insulin fraction of isolated pancreatic mouse islets in the presence of glucagon, theophylline and cyclic AMP. Diabetes 22:433-441

32. Lin BJ, Haist RE (1973) Effects of some modifiers of insulin secretion on insulin biosynthesis. Endocrinology 92:735-742

33. Buteau J, Roduit R, Susini S, Prentki M (1999) Glucagon-like peptide 1 promotes DNA synthesis, activates phosphatidylinositol 3-kinase and increases transcription factor pancreatic and duodenal homeobox gene 1 (PDX-1) DNA binding activity in beta (INS-1)-cells. Diabetologia 42:856-864

34. Wang Y, Perfetti R, Greig NH et al (1997) Glucagon-like peptide 1 can reverse the age-related decline in glucose tolerance in rats. J Clin Invest 99:2883-2889 
35. Perfetti R, Zhou J, Doyle ME, Egan JM (2000) Glucagon-like peptide 1 induces cell proliferation and pancreatic-duodenum homeobox-1 expression and increases endocrine cell mass in the pancreas of old, glucose-intolerant rats. Endocrinology 141:4600-4605

36. Oetjen E, Diedrich T, Eggers A, Eckert B, Knepel W (1994) Distinct properties of the cAMP-responsive element of the rat insulin I gene. J Biol Chem 269:27036-27044

37. Gasa R, Gomis R, Casamitjana R, Rivera F, Novials A (1997) Glucose regulation of islet amyloid polypeptide gene expression in rat pancreatic islets. Am J Physiol 272 (4 Pt 1): E543-E549
38. Zander M, Madsbad S, Madsen JL, Holst JJ (2002) Effect of 6week course of glucagon-like peptide 1 on glycaemic control, insulin sensitivity, and beta-cell function in type 2 diabetes: a parallel-group study. Lancet 359:824-830

39. Schatz H, Maier V, Hinz M, Nierle C, Pfeiffer EF (1972) The effect of tolbutamide and glibenclamide on the incorporation of $(3 \mathrm{H})$ leucine and on the conversion of proinsulin to insulin in isolated pancreatic islets. FEBS Lett 26:237-240

40. Mest HJ, Mentlein R (2005) Dipeptidyl peptidase inhibitors as new drugs for the treatment of type 2 diabetes. Diabetologia 48:616-620 